Claremont Colleges

Scholarship@ Claremont

CMC Faculty Publications and Research

CMC Faculty Scholarship

$1-1-2013$

\title{
Linkage Politics and the Persistence of National Policy Autonomy in Emerging Powers: Patents, Profits, and Patients in the Context of TRIPS Compliance
}

Aseema Sinha

Claremont Mckenna College

Tricia Olsen

University of Denver

\section{Recommended Citation}

Tricia Olsen and Aseema Sinha. "Linkage Politics and the Persistence of National Policy Autonomy in Emerging Powers: Patents, Profits, and Patients in the Context of TRIPS Compliance," Business and Politics, Volume 15, issue 3, 323-356

This Article is brought to you for free and open access by the CMC Faculty Scholarship at Scholarship @ Claremont. It has been accepted for inclusion in CMC Faculty Publications and Research by an authorized administrator of Scholarship @ Claremont. For more information, please contact scholarship@cuc.claremont.edu. 


\title{
Tricia D. Olsen and Aseema Sinha*
}

\section{Linkage politics and the persistence of national policy autonomy in emerging powers: patents, profits, and patients in the context of TRIPS compliance}

\begin{abstract}
The Trade Related Intellectual Property Agreement (TRIPS) has had a profound effect on industrialization and innovation, as well as access to medicines in cases of public health crisis such as HIV/AIDS. However, compliance with TRIPS has varied in developing countries, despite heightened international pressure. For instance, Brazil has pursued a coherent approach to its HIV/AIDS health crisis, while India has failed to take care of its HIV patients despite late compliance with the TRIPS agreement and the presence of business firms that produce the generic medicines for HIV/AIDS. This article suggests that divergence in TRIPS compliance is the result of a linkage politics, in which global variables (global rules, global supply chains and global networks) reach into the domestic political economy to alter the interests and capabilities of domestic actors. Indian pharmaceutical firms have developed external and export interests that lower incentives for the Indian state to design a nationally relevant public health policy, while the Brazilian health movement with its societal and external linkages puts pressure on the Brazilian state to defend the interests of its HIV patients even at the cost of patents. We conclude by suggesting that linkage politics is better at helping us understand compliance with international agreements than existing explanations, with important consequences for the effectiveness of international institutions.
\end{abstract}

*Corresponding author: Dr. Aseema Sinha, Wagener Chair in South Asian Politics and George R. Roberts Fellow, Claremont Mckenna College, 850 Columbia Avenue, Claremont, CA 91766, USA, e-mail: aseema.sinha@cmc.edu

Dr. Tricia D. Olsen: Assistant Professor, Daniels College of Business, University of Denver, Denver, CO 80210, USA

\section{Introduction}

A state's response to a public health crisis like HIV/AIDS reflects a nation's desire to care for its citizens. Global agreements such as the one regarding intellectual property (Trade Related Intellectual Property Agreement, hereafter TRIPS) seek 
to safeguard patents for private sector corporations, but also limit a state's ability to encourage indigenous production and ensure low cost medicines in cases of public health crises, such as HIV/AIDS. Tied in this trade-off, then, is a fight over intellectual property rights, with implications for the private sector's innovation profile and its capacity to supply medicines to its citizens. These trade-offs mean that global regulations create crucial dilemmas for many developing countries especially large, self-reliant countries such as India and Brazil. In doing so, they undermine the boundary of national autonomy that states hope to exercise in protecting the health of their citizens. As countries began implementing the global TRIPS agreement in the 1990s and 2000s, different actors - states, private business interests, and civil society - struggled with the trade-offs unleashed by changing markets and international rules, which created new dilemmas for state autonomy and business strategies alike. In response, global regulations and the reach of MNCs to set prices across the globe, prompted a global civil society campaign for access of drugs to poor patients. This fight over "access to medicines," then, "brings out the interplay of national and international dimensions and, in particular, the great challenges the national health systems of poorer countries confront on account of an international environment they can do very little to influence."1

Brazil and India, two emerging powers with similar state capacity, dealt with these emerging challenges differently. Brazil pursued an autonomous domestic approach to its health crisis, despite a compliant patent regime that made it more difficult to invoke such a national program. This program combined tough negotiations with MNCs with public provision of HIV medicines and an aggressive treatment program. India, recognized to be the "pharmacy to the developing world," incorporated key flexibilities in its legal framework but failed in designing a strong and coherent management of its HIV crisis despite having both domestic and international conditions that would have made such a response feasible and possible. Prevention was over treatment. India did not ensure that its own pharmaceutical producers, who were the primary providers of such medicines all over the world, provide cheap medicines to its patients. While India could not use compulsory licenses for the first line HIV/AIDS drugs as they were not patented in India, it could have used other measures to ensure cheaper and better treatment options for its citizens. In India, only $20 \%$ of HIV/AIDS patients receive anti-retroviral drugs, while in Brazil it is close to $60 \% .^{2}$

Why does Brazil have a more aggressive and comprehensive HIV/AIDS policy despite having a strong history of compliance with global rules that makes it more

1 Shadlen (2009); Pogge, Rimmer, and Rubenstein (2010).

2 The Indian data is from India's National AIDS Control organization. Also cited in Eimer and Lütz (2010). The Brazil data is from the World Development Indicators 2012. 
difficult to design an autonomous domestic program? Why does India have a less comprehensive HIV/AIDS policy despite having fewer restraints in terms of international compliance, a flexible domestic law that provides autonomy to local industry and a private sector that supplies low-cost HIV drugs to the rest of the world? India's behavior is especially puzzling as it points towards unexpected convergence with international norms while Brazil seems to challenge and exhibit greater national autonomy vis-à-vis its international obligations. What explains how strong states such as India and Brazil deal with the trade-offs created by an onerous global patent regime such as TRIPS and the need to address domestic needs such as the HIV/AIDS health crisis? We need further research into why states' responses to this crisis vary, with a particular focus on the differing capacity to deploy the flexibility provisions available within the TRIPS agreement. ${ }^{3}$

Recent scholarship on this topic examines the relationship between domestic strategy and international commitments by outlining the dilemmas that international commitment creates for states. We extend this extensive literature by focusing on the issue of how and why some states try to maintain domestic autonomy within the larger boundary of compliance. We propose a theory of linkage politics that suggests that global or systemic variables such as global rules, global supply chains and global networks reach into the domestic political economy - even in strong and self-regarding powers - to change the fundamental interests, and the capabilities, of domestic actors. ${ }^{4}$ In doing so, we propose a modification of the conventional wisdom that locates the sources of divergent autonomy to domestic level variables, while pressures for convergence are seen to arise only from the global levels. In contrast, we suggest that global level linkages (markets, rules, or networks) can provide the resources and incentives for domestic level autonomy and divergence as well as convergence. We argue that the divergence literature in comparative politics has mostly focused on domestic interests and institutions while neglecting the international linkages of domestic actors that shape the quantity, sustainability, and character of variable domestic responses. The international relations literature on convergence sees the global level as providing pressures and constraints rather than creating new winners that support globalization, as we argue here.

In our argument, then, countries' domestic policies vary not only because domestic actors have autonomy from global factors. Unexpected responses by both Brazil (stronger than one would expect given its early compliance with TRIPS) and India (weaker than one would expect given its advanced pharmaceutical

3 Sherrll, Somerville, and Bailey (1992); Boone and Batsell (2001); Lieberman (2005).

4 This resonates with the international organizations literature's interest in studying the effect of global rules of the game. 
industry and late and flexible compliance) can be explained by assessing how new domestic actors are activated or mobilized differently through their interactions with international actors, organizations, and networks. For Brazil, global societal linkages with its strong social movement for the right to health played a crucial role, while the emerging exporting and global material interests of the Indian pharmaceutical industry contributed to higher prices, and a defense of patents rather than patients. The internal and external linkages differentiate these new actors - including business actors and NGOs alike. Global factors and linkages create new domestic level actors and new capabilities, with widely varying capacity to respond to international pressure.

Employing a strategy of "paired comparison" or "nested comparison" 5 we offer some alternative mechanisms in our cross-regional comparison of India and Brazil. ${ }^{6}$ This article focuses on the linkages across levels (global and domestic linkages) and between state and society (intra-country linkages). The next section lays out the comparative puzzle in greater detail. Section 3 presents our theory of linkage politics, which focuses on how issues, ideas, people, and interests are linked across national and international arenas and their effect on state's responsiveness to HIV/AIDS. Sections 4 and 5 detail the case study analysis of India and Brazil. We conclude with a discussion of how this analysis can be extended to other cases of interest, South Africa and Thailand, thereby expanding the scope of our argument.

\section{The puzzle: variation in the trade-off between patents, profits, and patients}

Historically, India has resisted global pressures to comply with international agreements. India illustrated the ability to extract autonomy even in the face of global pressure by implementing the TRIPS agreement relatively late (2005) while countries like Brazil and China accepted the agreement in the mid 1990s. As a result, India did not begin issuing patents for pharmaceutical products until 2007 although it instituted a TRIPS consistent domestic law in 2005. Simultaneously, its national industrial policy created a uniquely indigenous capability to produce generic versions of the AIDS cocktail drugs. Given these historical dimensions of state desire and national capacity, India's response to its fast growing HIV/AIDS crisis should have been stronger and more effective. Yet, here emerges a puzzle:

5 Lieberman (2005); Tarrow (2010).

6 See Lieberman (2009); Shalden (2009); Eimer and Lutz (2010). 
India's response to the HIV/AIDS crisis has been slow and indifferent even though its domestic law incorporated some important provisions favoring its citizens. Why has India adopted a relatively ineffective approach to HIV/AIDS policies despite its high capacity to produce generic medicines and lack of constraints, namely the absence of patents on key antiretroviral medicines?

In contrast, Brazil complied with the TRIPS agreement early (1996) and began issuing patents at that time. Indeed, Brazil went beyond TRIPS requirements and also offered patents retroactively (so-called pipeline patents). At that time (1996), Brazil also lacked a diversified indigenous pharmaceutical sector with the ability to produce basic drugs. Yet, Brazil implemented a strong, well-designed strategy of both global importation of HIV/AIDS drugs and a domestic policy that ensures universal access to citizens affected by this disease. Why does Brazil have a more aggressive and comprehensive HIV policy despite having significantly less health-friendly patent policy?

This puzzle is illustrated in Figure 1, which maps out the policy changes in Brazil and India from an early period (t1: early 1990s) when both countries were faced with pressures to comply with the TRIPS agreement to a later period ( $\mathrm{t} 2$ : mid 2000s). The figure represents the trade-off between industry needs (patents) and domestic citizens' needs (patients). More specifically, the y-axis represents the spectrum of compliance. Brazil, for example, complied early (1996) with the

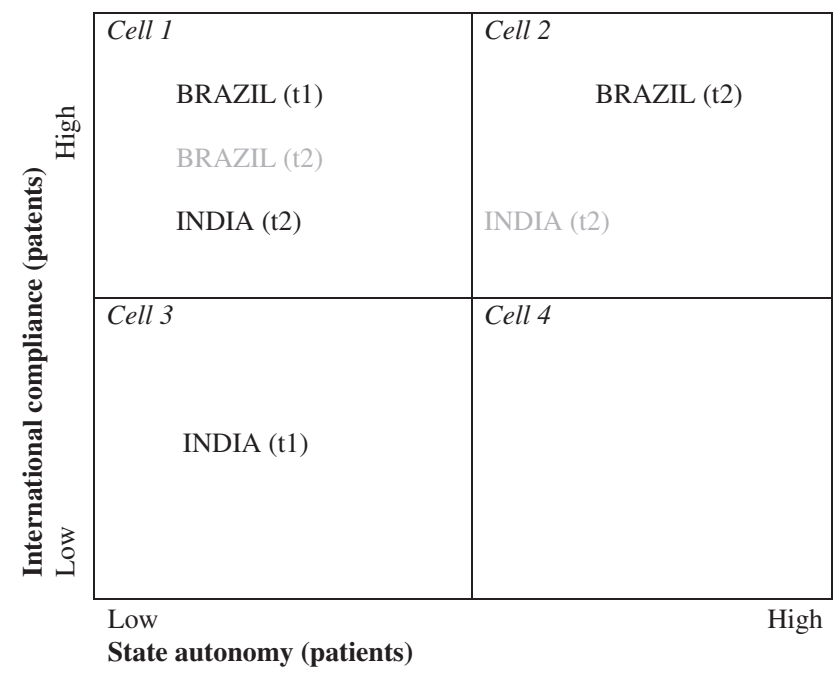

Figure 1 Expected (gray) and observed (black) policy trade-offs between state autonomy and TRIPS compliance. 
TRIPS agreement (see "Brazil (t1)") while India had low compliance in t1 and only complied with TRIPS in t2 (2005) with a number of flexibilities in its domestic regime. The $\mathrm{x}$-axis represents the spectrum of state autonomy.

Figure 1 illustrates that the expected policy response (in gray) is not the observed policy response (in black). International level explanations would predict that India - given its early resistance to the intellectual property rights regime - would have a higher level of state autonomy and would be in Cell 2. Comparative politics explanations would suggest India should be in Cell 3. Instead, we observe India's move from Cell 3 to Cell 1 between 1995 and 2005. In other words, India did not extract and expand its state autonomy while complying with TRIPS. Given Brazil's early adoption of TRIPS, we would expect Brazil - given its low capacity and high restraints in terms of early patents on pharmaceutical products - to maintain its position in Cell 1. Instead, we observe a move from Cell 1 to Cell 3 - from low state autonomy to high state autonomy, while still maintaining high compliance. This combined puzzle demands an answer. Why does India not seek autonomy, despite having the capacity to do so? How does Brazil successfully seek autonomy, even though it has substantial barriers in doing so?

At first glance domestic differences seem to accurately predict this variation in national responses. ${ }^{7}$ Gauri and Lieberman argue that a country's ethnic politics and what they call boundary institutions affect the state's ability to deal with HIV/AIDS. Eimer and Lutz argue that India's state implementation capacity is considerably weaker than Brazil's. ${ }^{8}$ Yet, these plausible conclusions render some elements of Brazil and India's engagement with TRIPS and the HIV/AIDS crisis puzzling. First, both countries are keen to signal to the outside world their acceptance of the global intellectual property rights regime. The global strategies of the two rising powers have changed toward greater interdependence and compliance in the last two decades; this development cannot be fully explained by a pure divergence-type argument. Second, the apparent differences in their responses to the HIV/AIDS crisis - the use of bargaining strategies vis-à-vis pharmaceutical companies and a more effective AIDS treatment strategy in Brazil compared to India - cannot be explained by domestic-level explanations alone. Pure domestic explanations are not wrong in explaining policy responses. What we are proposing is a more nuanced explanation that suggests that intra-state (domestic) and across state (external) linkages activate strong domestic responses even when domestic boundary institutions may suggest otherwise. And, India's weaker capacity outlined in Eimer and Lutz (2010) is due to the specific linkage mechanisms outlined here that render its state unable to bargain effectively with the

7 See Gauri and Lieberman (2006). Also see, Lieberman (2009).

8 Eimer and Lutz (2010). 
producers of these medicines. Theoretically, the conventional understanding of divergence renders the domestic and international realms separable from each other, at a time when greater interdependence, diffusion, and linkage across levels are evident.

We argue, instead, that variation in domestic responses is driven by the different ways in which the two country's pharmaceutical sectors and social movements are integrated at the domestic and global level. Despite similar compliance to TRIPS and similar state capacity in the two countries, Brazil's external and domestic linkages allow the state to resist global pressures, while India's pharmaceutical industry's external linkages, and weak intra-state linkages of social movements narrows the arena of autonomy for the Indian state. Simply put, the argument we make here is parallel to the argument made by Peter Evans in his classic monograph, Dependent Development (1997), in which he showed how international capital created domestic alliances and interests. Evans focused largely on industry interests; we also bring in the global networks of social movement actors who pressured Brazilian officials to design a national program in favor of both HIV patients as well as a domestic pharmaceutical industry. We find that domestic capital and domestic social movements are no longer an internal force whose interests are only tied to the national economy and domestic policy. Instead, domestic actors and organizations now operate globally, and share with global capital and global social movements an interest in global markets and global connections. This is not to deny some differentiation of domestic and multinational capital but to suggest that conflicts of interests are subtler and importantly, linkages and networks across the domestic and global arenas drive the extent and nature of "national autonomy." The strength of domestic networks is still important, but domestic strength is also affected by the degree of global linkages.

How does our argument modify the conventional wisdom on international and domestic interactions? Frieden and Rogowski argue that international economic changes - especially the easing of international exchange - have affected domestic politics in virtually every country. ${ }^{9}$ Yet, most scholars have found little support for the initial claims regarding the power of global forces to undermine national autonomy. Garrett argues that market integration co-exists with interventionist governments and greater policy divergence. ${ }^{10}$ Wade suggests that governments continue to retain national autonomy even in the face of increased interdependence. ${ }^{11}$ David Vogel, in another variant of this argument, notes that in

9 Frieden and Rogowski (1996: p. 25).

10 Garrett (1998).

11 Wade (1996). 
the field of environmental policy, global pressures facilitate an enhancement of environmental standards, or "trading up." ${ }^{12}$ We find that these debates are overly dichotomous: states either follow the dictates of globalization or they use their national autonomy to resist globalization. These binary categorizations offer no way of analyzing those situations where states strategically use their national autonomy to implement globalization - as is the case in large, powerful states such as India and Brazil. Clearly, we must go beyond discussions of divergence vs. convergence or compliance vs. resistance. In contrast, we focus on the mechanisms that transform and then sustain domestic responses, and the types of linkages both within a nation-state and in its external, global linkages. This complexity is better captured by "relative divergence" or divergence within a larger frame of compliance and interdependence.

The conventional wisdom holds that the international level is the source of constraint and compliance pressures, while the sources of divergence are traced to the power of domestic political institutions to "block or refract the effects of internationalization." ${ }^{13}$ Most analysts, when confronted with simultaneous cross-national variation and globalization, conclude that national policies and institutions create sources of variation and resistance to internationally rooted pressures and constraints. This article modifies the conventional wisdom that locates the sources of divergent autonomy to domestic level variables, while pressures for convergence are seen to arise only from the global levels. We argue that globalization itself has created new actors and new linked interests in domestic contexts that drive pro-globalization responses across even strong autonomous powers (India's pharmaceutical sector, for example). We, therefore, urge the need to examine the international linkages and interests of domestic actors that shape the quantity, sustainability, and character of variable domestic responses. Compliance with global rules and the implementation of globalization is being led by specific domestic actors and interests with increasing linkages and ties to the global realm.

\section{A theory of linkage politics}

Our theory of linkage politics compels us to explore the ways in which global and domestic arenas are linked to each other and the transformation of actors interests, preferences, and even identities that may result from these linkages. Two analytical questions are intrinsic to a theory of linkage. First, what is linkage

12 Vogel (1997).

13 Keohane and Milner (1996: p. 5). 
politics? Second, what do linkages do? That is, what effects do linkages have on actors across levels (domestic or international) and how do they balance their priorities? In order to build a theory of linkage politics that is capable of explaining both common actions of interdependence and compliance as well as variation in national responses, we draw upon the international relations debates on linkage politics. We also go beyond those debates to build new concepts.

The current understanding of linkage in international relations relies on the notion of externalities and trade-offs: when states act in two different - national and international - arenas simultaneously and their position in one arena affects their actions in the second. ${ }^{14}$ Bargaining game theory is used to analyze this basic idea of two-level or nested games. ${ }^{15}$ For Putnam, domestic incentives must be made consistent with a state's international behavior; that is, the domestic level drives the linkage Putnam (1988). Yet, as Eichengreen and Frieden argue, the linkage argument fails to address the problem of credibility, that is, the governments across the negotiating table must have some reliable sense that their actions will be sustained and not be backtracked. ${ }^{16}$ We build upon this insight and suggest that the literature on two-level games lacks a crucial link, as illustrated by its inability to provide a theory of how credibility is to be sustained when actors have interests tied to separable arenas and domains. Instead, we suggest that linkage theory must be able to explain how changing incentives and interests make actions across different levels consistent and credible. The current theory of two-level games lacks a clear understanding of the mechanisms that drives the transformation of interests and actions in a credible way.

We, thus, propose a theory of different types of mechanisms that enable actors and states located in different arenas to act in credible ways and to ensure sustained action. Sustained, credible action is only possible when interests and preferences in domestic arenas are transformed in the process of interacting across levels (Interest Linkage); when issues in one domain are linked with issues in other domains (Issue Linkage); and when the circulation of people, funds, and ideas (or information) follows the potential linkage of interests and issues (Carriers Linkage). ${ }^{17}$

Global interdependence creates new interests and new winners in domestic contexts. Specifically, export and technological links of the Indian pharmaceutical

14 Rosenau (1969); Keohane and Nye (1977); Tsebelis (1990).

15 Lohmann (1997).

16 Eichengreen and Frieden (1993).

17 The third mechanism - carrier linkage - is similar to the notion of networks outlined in Keck and Sikkink (1998). We posit that the notion of linkage is superior to the notion of networks, which connotes only horizontal relationships while linkages can encompass both horizontal and vertical (across global and national) interactions. 
industry makes this sector unreceptive to providing cheap treatment options within India. Analogously, the international public health movement framed issues in terms of the "human right to healthcare and treatment" as well as the universal right to affordable medicines, providing a different framing to local domestic social movements, which then, link with the local state and the pharmaceutical industry to extract autonomy against the global pressures in favor of a restrictive intellectual regime (Interest Linkage). Simultaneously, the issue framing in domestic contexts (Issue Linkage) as well as the domestic state-social movement linkages in terms of funds and people are very crucial to undergird a state's political will or capacity (Carrier Linkage).

While state action towards HIV patients is our dependent variable, unilateral notions of state power prove insufficient to explain the variation across our cases. Each of these three mechanisms - transformation of interests, issues linkage, and circulation of linking carriers (people, funds, and information/ideas) - are necessary to understand the variation in national responses to global rules. Thus, we define linkage politics not merely as the existence of nested games as in the exiting literature but the processes and mechanisms through which the nested character of different arenas (domestic-global and state-societal) is embodied and transformed. Linkage politics is the missing mechanism that transforms the existence of trade-offs and externalities within and across levels into influence and sustained action.

Linkage is a difficult variable to measure as it connotes relationships and interactions. We assess linkage in terms of three mechanisms: Interest Linkage; Issue Linkage; and Carrier Linkage or the extent of the flow of people, funds, and information across levels. First, interest linkage refers to the incentives that actors have to invest in certain action, for example, the incentives to produce medicines for the domestic vs. export markets. We measure interest linkages by: export of domestically produced generic drugs; the sales of medicines in regulated markets (US and Western Europe) as well as other external alliances; and the state's support of, or involvement in the generic sector.

Issue linkages are strong when issues or the way the issue is framed originates in, and is linked with, the political discourse in third countries or at the international level. This relationship is observed, for example, when access to medicines is framed as an issue of human rights domestically, which resonates with the international discourse; or the extent of government-civil society ties on HIV/AIDS related issues, including the government's participation in sectorinitiated domestic activities, such as conferences.

Both issue and interest linkage must transcend boundaries requiring carriers and modes of transmission (carrier linkage). The volume and intensity of circulation of people, funds, and ideas allows us to measure the extent of carriers' 
linkage. In concrete terms this can be measured by: the participation (and timing of participation) in international conferences; regular interactions and circulation of people across levels and arenas, sharing of information and resources, as well as strategic discussions between groups belonging to different levels (national/global and state/local); the presence of international philanthropic funding both by international organizations, and private donors. These factors, together, create carrier linkages, defined as the circulation of key actors, funds, and ideas across arenas.

The variation in linkage politics relies upon two variables: the strength of the domestic social movement sector and the strength of the domestic pharmaceutical industry. We measure these in terms of the strength of NGO networks; the breadth of their approach to HIV/AIDS; and the level of fragmentation among these groups. For attributes specific to the strength of the domestic pharmaceutical industry, we assess the size of domestic market share and the presence and strength of indigenous production.

In the following section, we discuss the logic of our paired case comparison and also outline how we measure the independent and dependent variables of interest. The remainder of the paper assesses the variation in the form and nature of linkage between national and international levels as well as between state and societal actors to understand the dynamics of TRIPS and responses to HIV/AIDS in India and Brazil. We conclude by discussing the generalizability of our theory and provide illustrative extensions to Thailand and South Africa.

\section{Case selection and measurement}

Methodologically, a cross-regional comparison - Brazil and India - goes against the grain of the usual cross-national but within-region studies in comparative politics. ${ }^{18}$ The two countries are similar in terms of area (although not the size of population), aggregate GDP, and the share of exports in the GDP, which leads us to expect that they will, generally speaking, respond to global "pressures" in similar ways. As emerging economies, India and Brazil have more in common with one another than they do with their regional neighbors. We argue that such cross-regional studies can be useful in addressing comparatively driven questions as well as analyzing issues of globalization, the effects of which go beyond regional groupings.

In the 1980s, the severity of the HIV/AIDS crisis was equally grave in India and Brazil. Table 1 summarizes the basic contours of the HIV/AIDS crisis across

18 For other important cross-regional studies see Kohli (2004). 
Table 1 AIDS crisis across cases.

\begin{tabular}{lrr}
\hline & Brazil & India \\
\hline Total population, in millions (2010) & 194.9 & 1170.9 \\
GDP, in billions (Constant USD) (2010) & 916.1 & 963.4 \\
GDP growth, annual\% (2010) $^{\text {Prevalence rates (2009) }}$ (19 $^{-19}$ & 7.49 & 8.81 \\
People living with AIDS & 0.6 & 0.3 \\
Deaths due to AIDS & $314,218^{\star}$ & $2,400,000$ \\
\hline
\end{tabular}

Source: World Development Indicators (2009/2010) and UNAIDS program (http://www.unaids. org/en/regionscountries/countries/). The data on people living with AIDS is from the CIA WorldFactbook.

*The Brazil data for "People living with Aids" is from and CIA "Progress Report on the Brazilian Response to HIV/AIDS (2010-2011)," Department of STD, AIDS and Viral Hepatitis (DDAHV), of the Health Surveillance Secretariat (HSS), Ministry of Health $(\mathrm{MoH})$, Brazil.

our cases. The first AIDS case in Brazil was reported in 1982. Only 8 years later, in 1990, there were 10,000 new cases. At that time, the epidemic in Brazil was often compared to that in South Africa. The "World Bank estimated that Brazil would experience 1,200,000 HIV infections by the year 2000, explicitly expressing the fear that the epidemic would then be totally out of control." ${ }^{20}$ Instead, the epidemic's growth rate had decreased by 1996; by 2004 it was believed that half of the projected 1.2 million HIV cases were averted. ${ }^{21}$ Today, the Brazilian Ministry of Health estimates that fewer than 200,000 people have HIV/AIDS.

India is home to one of the world's largest populations living with HIV/AIDS after South Africa, the worst affected nation in the world, and Nigeria. The first case was detected in 1986 and since then HIV/AIDS has rapidly spread throughout India. India's infection rate is nearly twice that of Brazil and India is home to 2.5 to 3.8 million reported HIV cases, the highest in South Asia and, again, third, after South Africa and Nigeria. ${ }^{22}$ Given India's population and its youthful character, the HIV/AIDS crisis, if unchecked, could have serious domestic consequences and gravely affect the global effort to curb the epidemic.

19 UNAIDS/WHO's Report on the Global AIDS Epidemic (2004) defines prevalence of HIV as the percentage of people ages 15-49 who are infected with HIV.

20 Levi and Vitória (2002).

21 Biehl (2004).

22 There is some controversy about the total number of HIV cases in India. In 2005 India was supposed to have around 5.6 million cases but a recent National Family Health Survey re-assessed that figure to around 2.5 million (this survey was conducted between 2005 and 2006, published in 2007). Unreported cases are likely to be much higher than other countries as there is cultural illiteracy about AIDS and social taboos about seeking tests for AIDS. 
Compliance with TRIPS occurred early in Brazil (1996) in comparison with India (2005), and yet, Brazil has clearly exhibited state autonomy vis-à-vis the international system in the post-compliance phase. Although common perceptions suggest that Brazil's utilization of the compulsory license in May 2007 and its threats to do so as early as $2001^{23}$ were rebellious acts, Brazil has a long history of complying with international law surrounding intellectual property rights and pharmaceuticals. In contrast, India's compliance record with international treaties has been more contentious, which might suggest that India would use the flexibilities provided by the TRIPS agreement. India was an aggressive opponent to the TRIPS agreements during the Uruguay Round and remained a lone voice of resistance to its passage after others agreed to sign on. Despite external pressure by the US, especially between 1995 and 1998, India did not comply, showing a rare ability to resist external "pressures" and only complied in 2005 after loosing at the WTO dispute-settlement court in 1997-1998; by doing so, it took full advantage of the transition period allowed under TRIPS. Moreover, the Indian amendment to the patent law in 2005 exploited most of the flexibilities available under the TRIPS agreement; its legal framework allows compulsory licenses and pharmaceutical exports to other developing countries without restrictions. ${ }^{24}$ The Indian implementation of the TRIPS agreement has been recognized to institute important autonomy for the state. ${ }^{25}$

Our dependent variable is the government response to the HIV/AIDS crisis, which has two dimensions that illustrate states' dilemmas (see Table 2). First, we measure international actions, which include compulsory license usage and bargaining with private MNCs to reduce prices of medicines. India could not use the compulsory license provision, as many of the HIV drugs were not under patent within India. Yet, Indian state officials were well positioned to negotiate with national firms to provide drugs at lower cost or issue compulsory licenses for second line treatment on which patents are still valid. ${ }^{26}$ We analyzed the prices of AIDS drugs available in the Indian market and found that they were higher than prices the same Indian firms were charging in Africa (Table 3). Second, we measure the domestic management of the HIV crisis and the state's commitment to addressing the health crisis by assessing whether the government response included HAART (highly active antiretroviral therapy), the timing of treatment options, and the government's matching funds (if any) with international

23 Cohen (2006).

24 Gupta (2008).

25 Article 3(d) for example.

26 The second line therapy is needed when patients become resistant to the early treatment drugs, which is very common. 
Table 2 Dependent variable: government response towards HIV/AIDS.

\begin{tabular}{|c|c|c|}
\hline & India & Brazil \\
\hline Government response & Failure & Success \\
\hline Price negotiations with MNCs and Indian firms & No & Yes \\
\hline Utilization of compulsory license & No* & $\begin{array}{l}\text { Yes } \\
\text { (May 2007) }\end{array}$ \\
\hline HAART (Highly active antiretroviral therapy) as part of initial response ${ }^{\star \star}$ & No & Yes \\
\hline Timing of antiretroviral therapy as part of a national program & $\begin{array}{l}\text { Late } \\
\text { (April 2004) }\end{array}$ & $\begin{array}{l}\text { Early } \\
(1989)\end{array}$ \\
\hline
\end{tabular}

*India could not have used CL for drugs, which were not patented in India as India started implementing patents late. So, India's use of CL only applies to second line and patented drugs. **Biomedical research has shown that treatment is extremely effective in stalling the progress of the disease and even in preventing new infections, as HIV/AIDS patients do not infect others while they are under treatment. The medical community has moved strongly in favor of highly active treatment therapy as controlling and preventing the disease in the future.

funding. International and domestic state actions, in our view, influence the severity of the crisis, which is measured in terms of the percentage of those with HIV/AIDS receiving ARV (antiretroviral) treatment and the reduction of HIV infection rates over time.

\section{Brazil: a surprising case of strong action}

The Brazilian state's response to the HIV/AIDS crisis has been strong, effective, and coherent. Since 1996, the government has reduced AIDS mortality rates by half and reduced hospitalization for HIV/AIDS by $80 \%{ }^{27}$ As a result, Brazil gained widespread international recognition for its work, including the UNESCO award for Human Rights and Culture of Peace in 2001; the UN AIDS Program award for their "leadership in improving the fight against the epidemic;" and the Gates Award for Global Health in 2003..$^{28}$ In addition, the World Health Organization asked the head of Brazil's National AIDS Program to help create an international policy to combat the disease. ${ }^{29}$

How did such a strong national response come about? In May 1985, as the military dictatorship was beginning the abertura (opening) of the political system,

27 St. Petersburg Times, 8 January 2006.

28 Ministry of Health of Brazil 2005.

29 Chicago Tribune, 8 June 2003. 


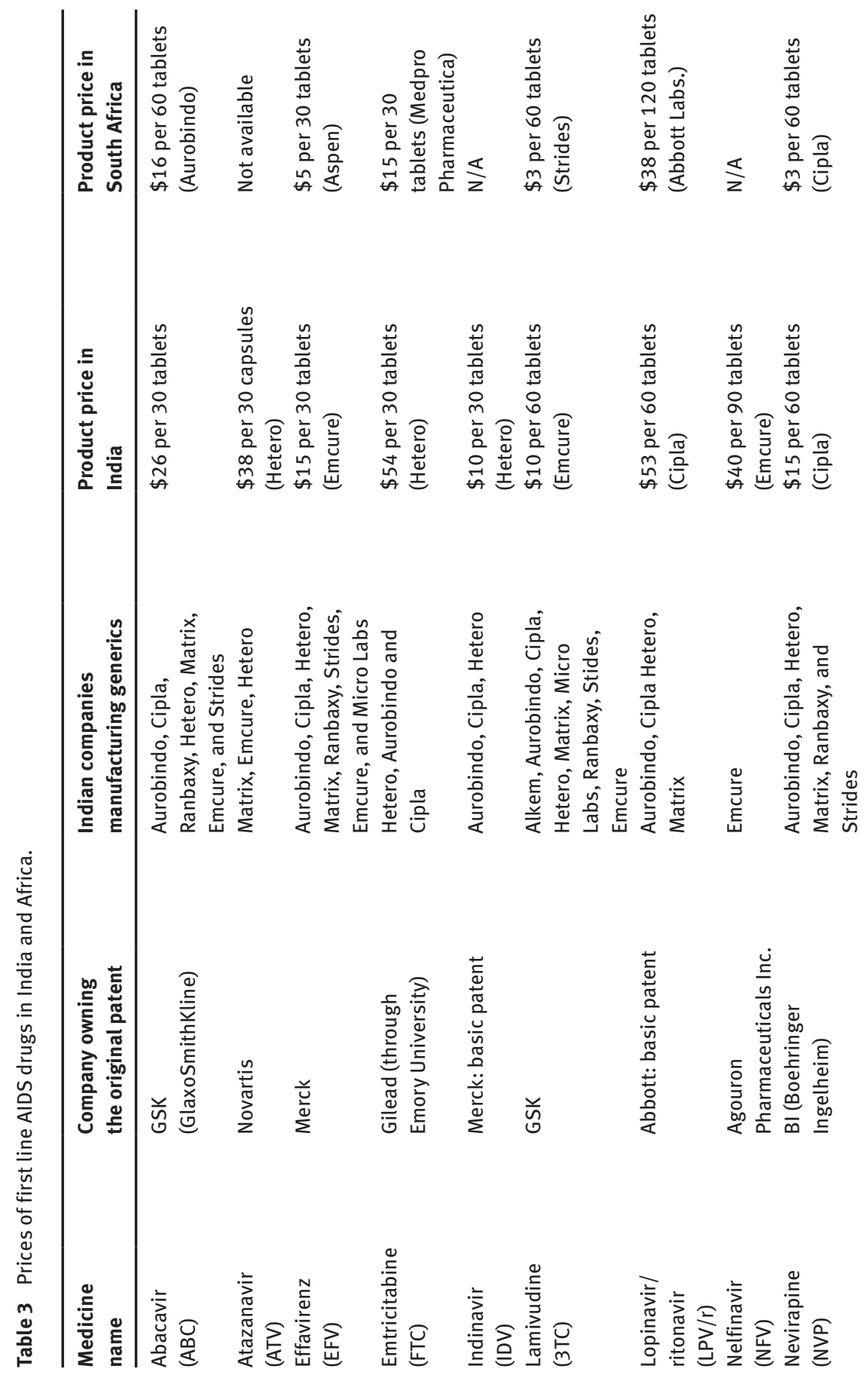




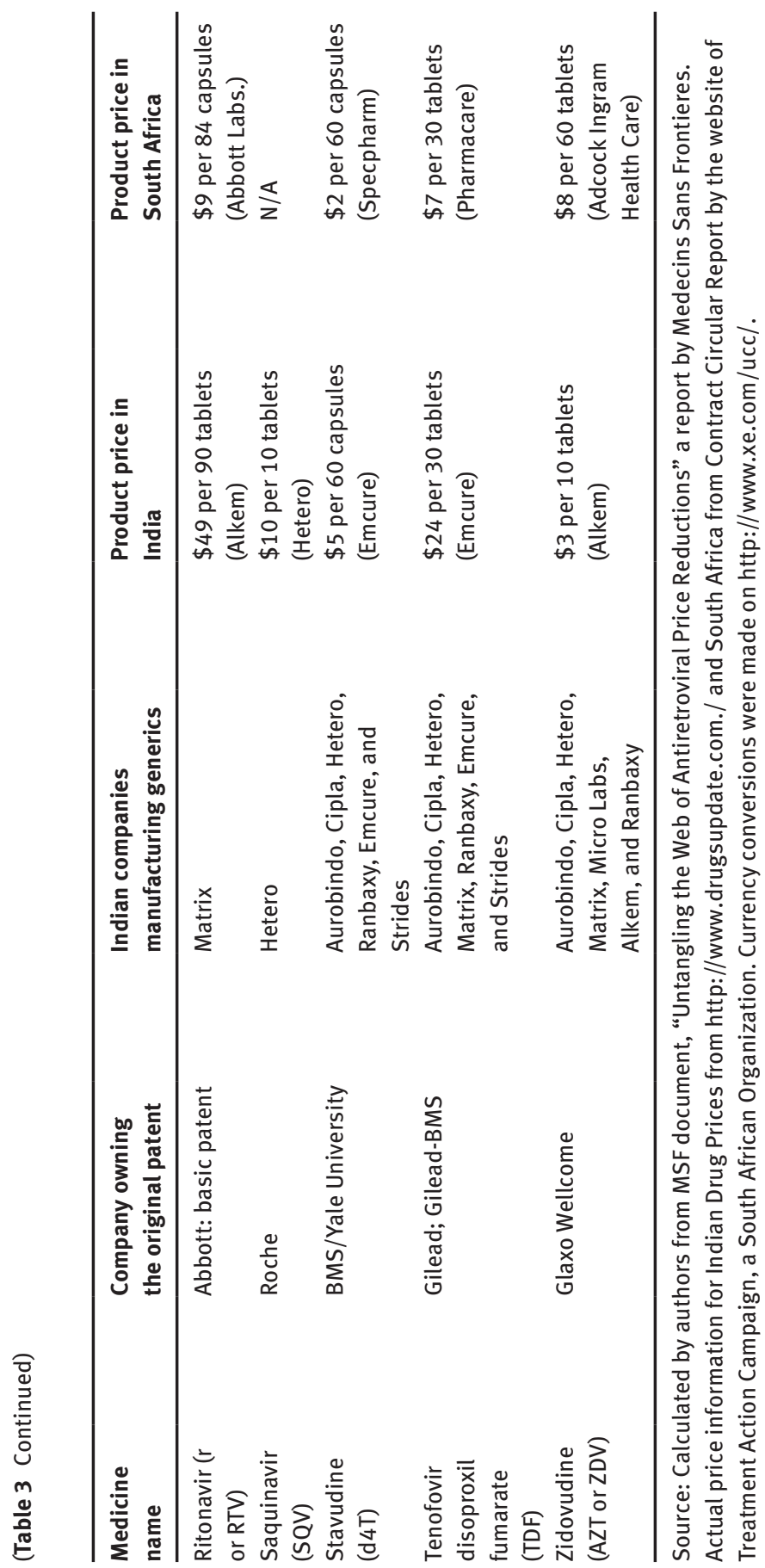


well-organized activists pushed the state to adopt an inclusive healthcare model, based on principles of citizen solidarity. ${ }^{30}$ In 1988, responding to civic commitment on this issue, the Ministry of Health established guidelines for the creation of the National AIDS Control Program (NACP) of Brazil ${ }^{31}$ and in unprecedented fashion, included health services as a constitutional right. ${ }^{32}$ The 1988 Constitution stipulates that all Brazilians have access to basic medicine and universal healthcare. This commitment - an important issue linkage (both domestically and, as explained below, internationally) - is the foundation upon which Brazil's successful prevention and treatment approach has achieved great gains. Civic and state actors had strong issue linkages throughout this period as democratic rights were linked to citizens' health rights and the state's obligation to ensure access to health services. In fact, the effort to transform "access to AIDS treatments from being an individual right into a collective right required additional legislation and state-based allies [for civic actors]." 33 Such linkages were important in encouraging the Brazilian government to guarantee free and universal access to HAART (antiretroviral treatment) for all citizens - a policy that was passed in 1996.

Issue linkages helped the government balance its international obligations and its responsibility to uphold the constitutional right to provide universal healthcare. One mechanism for doing so was to utilize protections consistent with TRIPS and the Doha declaration to articulate a strong commitment to domestic healthcare. For example, in 2001, the US challenged the legality of Brazil's domestic law in the WTO's dispute-settlement court. Brazil's patent law, Article 68, stipulates that compulsory licenses can be issued in situations in which the patent holder does not locally manufacture the product (known as the "local working" requirement). Responding to the US challenge of the law, the Brazilian state, with the help of domestic and international NGOs, launched a sophisticated international public relations campaign and, among other things, ran multiple advertisements in The New York Times that emphasized the normative principles of the universal right to healthcare. ${ }^{34}$ In the context of this legal challenge, the government utilized

30 Petchesky (2003).

31 Galvão (2000).

32 Berkman et al. (2005: p. 1162).

33 Flynn (2013: p. 8). Issue linkages were very strong, in part, because individuals that were part of a health reform movement, the sanitaristas, also became key figures in state health departments during the transition to democracy. It was these individuals, Flynn argues, who were "key protagonists in confronting patent monopolies and foreign pressure regarding Brazil's IP policies” (Flynn 2013: p. 9).

34 In June of 2001 an advertisement in the New York Times was signed by the government's STD/ AIDS program, the Brazilian Ministry of Health, the Brazilian National Network of People Living with HIV/AIDS, São Paulo State AIDS NGO Forum, and other Latin American AIDS NGO networks. 
Table 4 Comparative extensions of linkage politics and relative divergence.

\begin{tabular}{lll}
\hline & India & Brazil \\
\hline Government response & Failure & Success \\
Issue linkages & Weak & Strong \\
Framing of HIV/AIDS issue as human rights & No & Yes \\
Civil society - government ties & Weak & Strong \\
Interest linkages & Strong & Weak \\
Level of domestically-produced generic drugs & High & Low \\
Majority of sales in regulated markets & Yes & No \\
State's support of, or involvement in, generic sector & Uninvolved & Involved, main partner \\
Carrier linkages & Weak & Strong \\
Participation in international conferences & No & Yes \\
Regular interactions and circulation of people & No & Yes \\
across levels and arenas & & \\
Level of international funding for HIV/AIDS issue & Low & High \\
\hline
\end{tabular}

the existing issue and carrier linkages between domestic and international advocates to form powerful, strategic alliances with key INGOs, such as Oxfam and Medecins Sans Frontieres to fight the US-initiated legal challenge..$^{35}$ Brazil's issue linkage and carrier linkages originated with domestic social movement actors connecting to international activists. We argue that this link, combined with strong state capacity and an indigenous (though weak) pharmaceutical sector, explains the strong resistant behavior adopted by the Brazilian state.

\subsection{Indigenous pharmaceutical business capacity}

Unlike India, Brazil's domestic pharmaceutical industry focused primarily on the domestic consumer market and had few global linkages (see Table 4). Thus, it was a ready handmaiden to the national state's desire to fashion a strong response to the AIDS crisis. As such, it was able to generate generic competition, as well as the credible threat of local ARV production, which allowed Brazil to bargain effectively with the foreign MNCs for price reductions. ${ }^{36}$ Despite this indigenous capability, we argue that what was significant about Brazilian local pharmaceutical capability was that the Brazilian-owned industry developed to be a partner of - rather than a partner with - the Brazilian state, another impor-

35 Galvão (2002).

36 See discussion of the government-owned research laboratory and factory, Far-Manguinhos, in Petchesky (2003). 
tant interest linkage. First, the Brazilian pharmaceutical market share is small, and, more importantly, is predominately foreign-owned. Second, faced with an accelerating AIDS crisis, the Brazilian state took the initial steps in developing domestic local manufacturing capacity as well as importing medicines from Indian companies. The generic industry grew to meet domestic demand and maintained a strong focus on its patients. Unlike the Indian case, the Brazilian generic industry has not grown to be a powerful export sector of the Brazilian economy. Instead, its interests and incentives remained tied to national concerns, largely defined by the state.

The Brazilian state has worked to improve the development of domestically produced generic drugs. The Generic Drug Law, passed in 1999, took 8 years for approval and reduced the price for generic drugs considerably (by 25-30\%). ${ }^{37}$ In fact, a fundamental strategy for the Brazilian treatment program is the domestic production of some of the HIV/AIDS drugs. This domestically oriented interest linkage is further strengthened as "Brazil encourages new entrants in the generic market by offering preferential purchase options in public tenders and special financial investment conditions through state finance organizations." ${ }^{38}$ By 1999, 47\% of anti-retrovirals were acquired from domestic firms, of which $92.5 \%$ were from state-run laboratories, and $7.5 \%$ from private companies; by 2001 - just 2 years later - this share increased to 63\% by domestic firms. ${ }^{39}$ While India exports the majority of its generic drugs, the Brazilian public health care system purchases nearly all generic production as part of the government's HIV/AIDS program..$^{40}$ Thus, the state consciously cultivated intimate intra-state issue and interest linkages with the state-run laboratories and medical professionals..$^{41}$ These linkages also ensure that domestic state-expert carrier linkages are effectively harnessed toward addressing the larger HIV crisis by lowering the costs of local generic drug production and acquisition of antiretroviral drugs, often from Indian manufacturers, for Brazilian citizens.

37 Minister Serra has also promised to provide incentives for manufactures of generic drugs; Bruce (2003). This is especially interesting give that, at the time, Minister Serra was the candidate for president in 2002 from the incumbent party, PSDB (The Brazilian Social Democratic Party).

38 Galvão (2000).

39 Galvão (2002); Cohen and Lybecker (2005).

40 Cohen (2000).

41 Some note that the state's involvement has been to the detriment of local, private production of generic drugs - specifically ARVs - as the government crowds out their participation. See Flynn 2011. 


\subsection{Brazilian social movements}

Linkage politics in Brazil began with a well-organized, domestic-led NGO sector that reached out to International NGOs. The state followed suit with a strong response through legislation, media campaigns, and support for innovative HIV/ AIDS treatment and education programs. The transition to democracy created an active, dense, and diverse set of civic organizations that worked on HIV/AIDS issues prior to federal and/or international involvement, thereby establishing solid domestically based carrier linkages. As early as 1983, a group of gay activists called Other Thing (Outra Coisa) began distributing pamphlets about HIV/AIDS and HIV prevention in São Paulo. As the disease initially affected white, uppermiddle class gay men, many of whom were heavily involved in the civic activism against the dictatorship, the issue of HIV/AIDS could not be sidelined and, instead, was "pushed to the forefront of the national consciousness." ${ }^{42}$ A group of middle-class educated, urban women, who originally offered support to those infected with leprosy, began offering their services to HIV/AIDS patients as early as 1984 and just a few years later, the Catholic Church and other religious organizations also became involved..$^{43}$ Activists formed the first AIDS-specific organization, AIDS Support and Prevention Group (GAPA, Grupo de Apoio à Prevenção à AIDS) in São Paulo in 1985 and the Brazilian Interdisciplinary Association of AIDS (ABIA, Associação Brasileira Interdisciplinar de AIDS) in Rio de Janeiro in 1986. GAPA and ABIA established numerous satellite organizations throughout the country, all of which increased awareness of HIV/AIDS and criticized the government for not addressing the epidemic. Initially, all organizations were comprised of volunteers, as no government or international funding was available at the early-to-mid 1980s. Brazilian HIV/AIDS NGOs held national meetings which, in 1989 , comprised of 30 people from 14 organizations and grew to include nearly 90 different organizations as early as $1992 .{ }^{44}$

Given the strength and heterogeneity of domestic NGO activity, it is no surprise that leaders from these organizations took the initiative to become involved in, and solidify carrier linkages with international NGOs. ABIA and GAPA, among others, participated in the International Conference on AIDS held in Montreal in 1989. There, Brazilian HIV/AIDS activists worked to create an international network of organizations working with AIDS, called the International Council of AIDS Services Organizations (ICASO). In fact, Brazilian NGO activists were the first to receive international funding from the Ford Foundation in 1989 due to connections they had

42 Toronto Star, 5 August 2006.

43 Galvão (2000: pp. 57-59, 73-74).

44 Galvão (2000: pp. 60, 62, 89-92). 
made with academics and activists working in the US. The diversity of the groups working on HIV/AIDS, in combination with their ties to the international community - especially during a time of increased political openness - made the Brazilian state take notice. ${ }^{45}$ Civic organizations used this political opening to solidify citizens' right to healthcare (Article 196 in the 1988 Constitution), access to basic medicines, ${ }^{46}$ and worked to apply this provision for HIV/AIDS patients: federal law 9313. This law, passed in 1996, mandated the free and universal provision of HAART through the public health system. In addition, government officials established a HAART Support Committee, which is completely independent of the Ministry of Health. ${ }^{47}$

Importantly, the national government began to work closely with Brazilian NGOs consolidating essential issue and carrier linkages within Brazil. In 1992, the Ministry of Health participated in the organization of the fifth National Meeting of AIDS NGOs. With support from domestic NGOs, Brazilian politicians approached the World Bank in the 1990s, at a time when the World Bank had yet to establish an explicit HIV/AIDS strategy. The World Bank noted that the Brazilian government's “commitment to fighting HIV/AIDS preceded Bank involvement, and general prevention programs almost certainly would have occurred even without the [World Bank] projects." ${ }^{48}$ By 1994, with funding from the World Bank, the government financed many of the same organizations that also participated in the National AIDS Commission, a government advisory committee. ${ }^{49}$ Clearly, there were regular overlaps and circulation of key people between the governmental and civil society organizations.

With a weak, domestically owned pharmaceutical sector and a relatively strong state, Brazilian activists were able to put HIV/AIDS on the agenda. Due to strong issue (human and democratic rights and health rights were linked to each other) and carrier linkages, activists kept HIV/AIDS on the agenda. Civic activists continued to partner with the state while still holding the state accountable for its earlier promises. Many argue that, "[a] principal reason behind the Brazilian government's strong commitment to the HIV/AIDS program, particularly with regards to the free and widespread distribution of antiretroviral, is the effective, well-organized lobbying from civil society." ${ }^{50}$ A notably strong domestic

45 For a description of the sanitarista movement, to which many of these groups belonged, see Flynn (2008).

46 Article 196 states that "health is a right of all and a duty of the state," guaranteeing universal and equal access to health services, provided for free by the government.

47 Levi and Vitória (2002).

48 Beyrer et al. (2005: p. 42).

49 Osava (2008).

50 See Galvão (2002: p. 1862); Flynn (2011: p. 153); Petchesky (2003: p. 95) notes that former activists became strong advocates for reform within the government itself. 
and international community of HIV/AIDS activists played a key role in Brazilian state's response to this epidemic. When the Brazilian state decided to negotiate lower prices and eventually issued a compulsory license, there were already significant issue and carrier linkages that provided domestic support for such efforts. In sum, we argue that Brazil's strong state, weak pharmaceutical sector, and the presence of linkage politics between domestic social movements and international activists has allowed Brazil to actively follow their HIV/AIDS policy, even while complying at the international level.

\section{India: the dog that did not bark ${ }^{51}$}

In contrast to Brazil, the Indian state's response has been slow, fragmented, and ineffective. This is especially puzzling given India's state capacity in other domains, and the presence of a pharmaceutical industry able to produce generic medicines for HIV/AIDS. Though the government launched a national program in 1987 and followed this with the establishment of the National AIDS Control Organization (NACO) in 1992, the rate of people being treated with HAART remains very low..$^{2}$ Only 6 to $15 \%$ of patients have access to the regular dosage of antiretroviral drugs ${ }^{53}$ and availability of the cocktail drugs is very limited. A report in The Hindu states that "[c]ompared to the universal programme of Brazil, the government of India's attitude can only be described as criminal."54 Joanne Csete, Director of the HIV/AIDS program at Human Rights Watch noted: "It is a sad irony that India is one of the biggest producers of the drugs that have transformed the lives of people with AIDS in wealthy countries. But, for millions of Indians, access to these medicines is a distant dream." ${ }^{55}$ The Indian experience reveals that a state's ability to produce medicines and its willingness and ability to provide reasonable and cheap access to HIV/AIDS medicines to patients need not go together. ${ }^{56}$

51 This idea comes from the short story, "Silver Glaze” featuring Sherlock Holmes, where Holmes noted the "curious incident that the dog that did not bark at night."

52 World Health Organization 2007. A World Bank loan for AIDS prevention led to the establishment of NACO, as the World Bank loan required a national coordinated response. See Dube (1992).

53 The Hindu, 23 February 2001: p. 19. This is in stark contrast to Brazil, where it is estimated that $80 \%$ of those in need of ARVs can access them, a notably high rate of coverage worldwide. UNAIDS 2008.

54 The Hindu, 23 February 2001: p. 19.

55 Human Rights News 2002.

56 We thank an independent reviewer for this formulation. 
In 2001, Cipla, an Indian-based pharmaceutical company, made a dramatic offer to sell a three-drug cocktail at $\$ 350$ a year for one person to Medecins Sans Frontieres for free distribution in its HIV/AIDS programs in Africa (and at $\$ 600$ to governments in Africa). In India, the same cocktail is priced from $\$ 1100$ to $\$ 2000$ a year (according to Cipla). ${ }^{57}$ Paradoxically, Cipla proposed prices for Viraday, its latest version of the HIV/AIDS cocktail, were twice as high in India as in Africa. ${ }^{58}$ The owner of Cipla, however, blames the Indian government. In the 1990s, Cipla was asked by the Indian Council on Medical Research to create a generic version of Glaxo Wellcome's AZT, the first HIV/AIDS medicine. While Cipla sank resources into successfully replicating the drug, the Indian government announced it would spend its money on prevention, not treatment. ${ }^{59}$

India's incorporation of treatment as part of its domestic strategy was delayed and ineffective. In December 2003, the government requested public sector hospitals in six out of 28 states to provide treatment ${ }^{60}$ and in April 2004 India began distributing free ARV drugs to about 100,000 poor HIV/AIDS patients. Only in 2007 did the Indian government declare HIV/AIDS a national emergency and even then, a coherent state-led program of ensuring access to affordable drugs and prevention programs was lacking. ${ }^{61}$ India did not have a treatment strategy until very recently. The Indian state also has shown no desire to deploy the exceptions provided in the TRIPS agreement on behalf of its citizens. While India could not use the compulsory license provision in the same way given its internal capacity to produce drugs, the Indian state never negotiated with its pharmaceutical firms to lower prices, as did Brazil and Thailand..$^{62}$

What is striking is that the same pharmaceutical firms sell the HIV/AIDS cocktail drugs within India at higher prices than they sell in Africa and even

57 Dr. Kumaasamy of the YRG center for AIDS Research and Education claims that it cost a patient around \$1500-2000 a year, see The Hindu, 23 February 2001: p. 19.

58 The Financial Times, 30 March 2008: p. 1-2.

59 The Financial Times, 30 March 2008: p. 1-2.

60 World Health Organization 2007.

61 After severe criticism, the Indian government did initiate some key policy changes. In 2007, the government reported using $\$ 2$ billion to fight the disease, provided free antiretroviral treat to 75,000 people, and set up 3500 free testing centers. See, The New York Times, 8 June 2007.

62 In March 2008 India's patent controller issued the country's first compulsory license to NATCO for Bayer's Nexavar, a medicine for kidney cancer but a compulsory license for the second line AIDS drugs may be more urgent. Similarly, the Gleevec case is relevant. Novartis filed a case in 2007 requesting a patent for its new medicine and has appealed to the Supreme Court of India to uphold the patent of its new drug for cancer. In April 2013, the Supreme Court ruled against Novartis, stating the patent could not be provided because the drug is too similar to the earlier version. See New York Times, 4 April 2013. While the Indian judicial system is acting in favor of Indian patients, the state has not used these debates to provide better treatment options for HIV/AIDS, a disease that affects a much larger number of patients in India. 
Brazil. Table 3 shows this discrepancy, wherein each drug is sold at higher prices in India despite the easy availability of that drug by Indian firms. Around 800 million people in India live on less than $\$ 2$ dollars a day and would surely benefit from having a lower price. Thus, Indian patients do not benefit from India's late entry into TRIPS nor by the productive capacity of the firms to produce those drugs cheaply. Clearly, India continues to lack a comprehensive strategy and institutional response to the HIV/AIDS crisis while Brazil's commitment has been strong since the early 1990s.

Could India's poor health infrastructure especially in the government sector be responsible for such negative outcomes for HIV/AIDS? India's health model is one of private and nongovernmental provision for health, ${ }^{63}$ with its attendant negative effects for any public health crisis such as lack of insurance, lack of comprehensive health management and a focus on family planning. Moreover, the continued presence of such common diseases such as gastroenteritis, tuberculosis, and malaria preoccupies the health infrastructure. Could the weakness of its health structure have been responsible for India's weak response to HIV/AIDS? Weak health capacity certainly played a part in India's inability to scale up treatment options. In countries such as Thailand and Brazil, the government used its public health system to provide cheap treatment options. Even so, Brazil's health infrastructure was also very weak before the HIV/AIDS crisis.

In 1995 Brazil spent $6.6 \%$ of its GDP on health while India spent $4.2 \%$, which is not a significant difference. However, by 2010, Brazil expenditure had increased to $9 \%$ and India's had declined to $4 \% .{ }^{64}$ It is this expansion in health expenditure that reveals the story of variation across India and Brazil rather than the initial health base. In Thailand and Brazil, for example, the urgency of the HIV/AIDS crisis led the government to build and strengthen its health system. Dr. Mauro Schechter, Chief of HIV/AIDS research at the Federal University in Rio notes "Brazil's success is remarkable because it was built atop a shaky health system that was not fully set up to deliver complex treatment.” In his view Brazil integrated treatment and prevention in a way that was not seen as a model before. ${ }^{65}$ In India, this did not happen. Thus, while India's weak health system may have been an obstacle to creating a coherent HIV/AIDS treatment model, the HIV/AIDS crisis could have served as a stimulant to its strengthening if other linkage such as a locally oriented pharmaceutical industry or a well-linked domestic social movement existed in India. In Brazil, HIV/AIDS activists demanded reform and

63 Berman (1998).

64 Data are from World Development Indicators 2012. Calculated by authors.

65 Toronto Star, 5 August 2006. 
renewal of the health infrastructure and the state responded with an expansion and improvement of its health infrastructure. ${ }^{66}$ The state has failed its HIV/AIDS patients in India, despite not in spite of, its health infrastructure.

\subsection{Indigenous pharmaceutical business capacity}

India's pharmaceutical sector is uniquely capable of addressing India's need for affordable medicines for the HIV/AIDS epidemic. Yet, with changing global rules and shifting interest linkages of the industry, its preferences moved away from responding to the domestic crisis and became oriented toward export markets and global supply chains both in terms of production and innovation. This global integration of domestic firms contributed to an indifferent domestic response in favor of cheap prices for HIV/AIDS drugs despite the possibility and the capacity for an aggressive pro-treatment strategy at home. Equally as important, issue linkages with the state on behalf of HIV/AIDS patients were lacking, which contributed to an incoherent response toward the HIV/AIDS crisis (see Table 4).

India's pharmaceutical sector enjoys domestic strength and global preeminence. The domestic firms control $77 \%$ of the domestic market. ${ }^{67}$ It is one of the few industries able to produce the HIV/AIDS cocktail medicines cheaply and in such high quantity so as to provide them to African, Asian, and Latin American countries. ${ }^{68}$ Paradoxically, its strong global interest linkages - exporting power as the supplier of generic medicines to the rest of the world - transformed the pharmaceutical sector's preferences in favor of stronger patent protection and requirements to secure export markets in regulated and unregulated markets. Its exports increased from \$47.9 million to \$3177.3 million in 2003-2004; and exports have grown at the rate of $20.8 \%$ since $1995-1996 .{ }^{69}$ Moreover, stronger competition with multinational corporations in India and in export markets after the onset of patents, and a restrictive regulatory regime in India put greater pressure on margins and profits, increasing the incentive to capture new export markets.

66 While health policy scholars are critical of the progress Brazil has made in terms of its infrastructure and capacity to provide healthcare to HIV/AIDS patients, relative improvements have been made. Such improvements are also impressive when compared with India. See, for example, a broad discussion of the changes made in Brazil's public health system, in response to the HIV/AIDS epidemic in Berkman (2005). For a more critical perspective on the improvements that still need to be made, see Gómez (2011); Elias and Cohn (2003).

67 Chaudhuri (2005).

68 The World Health Organization 2007 lists four companies able to produce HIV/AIDS therapy and three of the firms are from India: Cipla; Hetero Drugs Limited; Ranbaxy; and Matrix Laboratories. 69 Chaudhuri (2005). 
The US, with the toughest regulatory requirements, emerged as the largest export destination for Indian firms. In fact, the US market now accounts for sizeable revenues for Indian companies: 32\% in the case of Dr. Reddy's and 42\% for Ranbaxy. ${ }^{70}$ After 2001, markets with extremely high HIV/AIDS infections - namely, Africa - also became significant. Indian firms began to target generic markets in the US and EU, both in terms of exports, manufacturing, as well as acquisitions, FDA approvals, and patent protection in regulated markets. Indian pharmaceutical firms also began marketing and manufacturing in these markets, which led them to comply with the TRIPS within their own operations. Ranbaxy, for example, has 32 subsidiaries in 19 countries; Dr. Reddy's has 14 in 9 countries; and Sun Pharma has 4 subsidiaries. Many of these companies also manufacture outside of India. By now, exports, regulatory issues in developed markets, and the need to secure new markets dominate the market and political strategies - and interest linkages - of Indian firms. As such, their market strategies have catalyzed strategic alliances and linkages between domestic and foreign firms. ${ }^{71}$

Both private sector actors and some government officials became supporters of the patent system, creating new interests in favor of implementing TRIPS rather than using it to provide cheaper drugs domestically. Parvinder Singh, Ranbaxy's CEO, led a crusade in the 1990s to persuade the government and other industry actors to change their practices and accept the TRIPS regime. ${ }^{72}$ He noted: "[Ranbaxy] realized that you can not afford to isolate yourself if you want to globalize. To sell in the international market, Indian companies have to play according to the host country's rules."73 Similarly, Dr. Reddy's Laboratories learned to use the US patent system and play by globally consistent patent rules. In the early 2000s, a split within Indian pharmaceutical ranks led to the creation of an association of 11 large research-based national companies, which began to support the patent regime. ${ }^{74}$ These changing interests and strategies make Indian pharmaceuticals more supportive of the international system of patents, and moderate in their nationalist stance regarding national interventions on behalf of crises such as HIV/AIDS, with the sole exception of Cipla's Dr. Hameid.

70 Rangnekar (2006).

71 Ip-health Listerserv 1 May 2007.

72 Singh has stated this viewpoint elsewhere: "The government has to understand the urgency of liberalizing and freeing our industry from price and profit controls, which have continued to hurt the growth of our industry. In the light of the GATT decision, the industry must be freed so that those that are efficient are able to function effectively and thereby fund much larger outlays into research, because the key to survival will lie in this” The Telegraph 23 January 1994.

73 Business Standard 10 November 1993. This data is drawn from the author's book project Aseema Sinha (Unpublished book Ms titled: When David Meets Goliath: How Global Trade and Rules are Changing India's Rise to Power).

74 Cipla left this association in opposition against their stance on patents. 
Moreover, Indian pharmaceutical companies prefer to sell HIV/AIDS drugs in countries with strong state intervention on behalf of HIV/AIDS patients (such as Brazil or Thailand), where the government or a NGO procures medicines from exporting or domestic companies and then distributes them through the public health system. This ensures a secure market and a large market share, both are prerequisites for the low prices offered by Indian companies. In the absence of such state intervention for HIV/AIDS patients, Indian pharmaceutical majors have no interest in selling their products domestically. In India, the export and global interests of private firms are in line with the state's lack of interest in addressing India's HIV/AIDS crisis and weak state-private sector linkages. Thus, prices of HIV/AIDS cocktail are much higher in India, the country that produces them, than in Africa where government commitment as well as generic competition has ensured a domestic strategy for expansion of treatment as well as affordable pharmaceuticals (see Table 3).

\subsection{Indian social movements}

Strong global interest linkages of India's private sector (in terms of production, markets, and technological innovation) were complemented by a weak and delayed issue linkage of the HIV/ADIS activists. Most crucially, the social movement advocates HIV/AIDS were fragmented, and largely focused on prevention and education rather than treatment. Internal issue linkages between NGOs and state actors were clearly lacking; in fact, the interactions were often distant and even hostile. ${ }^{75}$ In contrast to Brazil, were very few Indian NGOs focused exclusively on HIV/AIDS work or access to healthcare and treatment. Moreover, civil society activism on the AIDS crisis started quite late, around 2001-2004, when international aid and financing began to flow to local NGOs. ${ }^{76}$ By then, the fight for universal access of healthcare could not gain momentum. Indian AIDS activ-

75 There are important exceptions to this pattern within India, when state and NGO actors have come together (linkage politics) to design innovative strategies and programs to deal with the crisis. For instance, the Sonagachi program in the red light strict of Calcutta, West Bengal (East India) became successful when the project's administration was transferred in 1999 from the government agency to a cooperative society that included government agencies, sex workers, and NGOs. See Nag (2005).

76 Lawyer's Collective started its HIV/AIDS initiative in 2001; Stop HIV/AIDS initiative (SHAII) was set up in 2004. Naz Foundation, one of the early organizations to focus on HIV (starting 1994), has focused its attention on legal challenges. Hamsafar Trust started some projects in 1999 but most of its programs started in 2001 with funds from USAID. Almost all NGOs started more programs for education and prevention after 2001 when international aid and NGO help increased dramatically. 
ists focused on educating high-risk groups (sex workers and truckers) about cultural aspects of the disease (social taboos including talking about using condoms and sex), rather than uniting all aspects into one common and universal issue: the human right to access basic medicine. Without framing the issue as a human right to health, public health campaigns, while extremely courageous and important, lacked the ability to target the state for its failure to provide a basic right to its citizens.

In addition, activist groups failed to unify the diverse segments of the HIV/ AIDS population. Under Indian law section 377 of the Indian penal code, known as the anti-sodomy law, gay men can be arrested for "unnatural acts." This act criminalizes same-sex behavior. This stark fact, of course, limited the possibility of organizing among the gay community and delayed activism. Gay activism, in fact, developed in part over the HIV/AIDS crisis, when the Naz Foundation was founded in 1994 as an HIV/AIDS outreach organization and went on onto to focus on all aspects of gay life and discrimination. HIV has created the opportunity for this sector of the population to organize and mobilize. ${ }^{77}$ Yet, given the extreme social and cultural taboos in India, most gay organizations focus on the social aspects of the disease and do not target the government or the private sector for improved access to treatment. Gay organizations realized that, "to fight AIDS, activists found they had to fight homophobia, including section 377."78 Despite this activism, gay activists have not been well received. In 2004, activists were arrested for distributing health related work on AIDS. ${ }^{79}$ As a result, universal health care for the gay community has not yet become an important issue.

Interestingly, AIDS activism among other high-risk communities - sex workers and truckers (a key group with a high prevalence of the disease) - has been more successful and focused on education, information and breaking cultural barriers, rather than on access to health care. In the Brazilian case, civil society's focus on the state's responsibility toward health care and universal access to drugs had the unintended effect of linking all actors behind a feasible and observable action, in the process achieving those goals. The Indian HIV/AIDS movement, with notable victories and campaigns, has failed to unite different kinds of issues, programs, and communities affected by HIV/AIDS. Despite their partial, though delayed, vibrancy, these diverse groups are unable to solidify the same issue and carrier linkages that would allow a unified campaign against the state or to mobilize the state to put pressure on the private companies to ensure

77 Author's interview with an activist from the Lawyer's Collective, New Delhi, India, January 2007. 78 The Gully Online Magazine, 18 October 2004.

79 NPR, 25 August 2004. 
affordable access to drugs. Thus, in India, the indigenous social movement is fragmented, weak, and lacked crucial issue and carrier linkages with both the state and international organizations. Overall, India's HIV/AIDS activism came late and lacked strong domestic and global interactions and alliances.

\section{Conclusion: implications and comparative extensions}

Our main theoretical contribution is in outlining a more nuanced theory of linkage politics to explain variation in national responses. In our view, scholars can no longer treat the international level as an exogenous variable that affects domestic economies externally. We conceptualize of international effects not merely as "pressure" but in a more complex way, arguing for the need to look at the extent and nature of linkages, and new domestic interests activated by globalization. In doing so, we challenge the conventional view among both comparative politics and international relations scholarship, which suggests that domestic differences alone drive divergence in national responses to global developments. Scholars from both subfields suppose that domestic-level explanations provide room to maneuver while international markets and agreements are constraining. We argue the reverse: International linkages, under some circumstances, may increase the room for domestic actors to maneuver. This refinement, in turn, allows us to look at domestic and international variables not in isolation but explore the interactions and relationships among them.

Using the theoretical model developed in this article, we analyze Thailand and South Africa's responses to the HIV/AIDS crisis. In Thailand strong issue and carrier linkages played a crucial role in effectively addressing the HIV/AIDS crisis despite a relatively weak pharmaceutical sector. ${ }^{80}$ Shortly after 1984 , when the first case of AIDS was documented, a national reporting system was implemented. ${ }^{81}$ This surveillance program, combined with a proactive treatment and education program and the involvement of HIV/AIDS NGOs led to Thailand's "significant success in controlling the spread of HIV, with new infections falling from 143,000 cases in 1991 to 23,000 in 2002." "82 Meanwhile, the Thai state established a symbiotic relationship with the private health care sector: doctors work in both public and private clinics and nearly all health professionals are trained at public

80 Supakankunti et al. (2001).

81 Beck and Holland (2006: p. 353).

82 Beck and Holland (2006: p. 354). 
expense. This ensured strong domestic issue and carrier linkages. In congruence with our argument, information flows and overlaps between different civil society actors (carrier linkage) created pressure on, and a strong incentive for, the Thai state to respond to the health crisis. In addition to strong intra-state ties between the state and the health care sector, Thai NGOs were in place to fulfill a leading role in advocating a strong response to the role of patent protection and HIV/AIDS. ${ }^{83}$ Like the Brazilian case, Thai NGOs also had strong ties to international organizations. Medecins Sans Frontieres began working in Thailand in 1994, quite early, and by invitation from local NGOs (issue and carrier linkages). During this time, the government began to move away from using brand-name drugs and sought to strengthen the domestic generic sector and an expansion of treatment provision. In November 2006 and again in January 2007, the Thai government issued compulsory licenses for HIV drugs. ${ }^{84}$ Despite Merck's offer to sell their drug at a "no-profit" price, the government could provide it at half the price by producing a generic version. Thus, Thailand's policy response has been relatively effective and timely, despite lacking - initially - a strong generic market. This can be explained by the strength of their strong issue and carrier linkages in the social movement sector and symbiotic domestic state-society interactions over public health issues.

South Africa has had surprising success in ensuring that treatment options could potentially become accessible for its population, but also failed to translate those potential gains into concrete outputs. This paradox can be explained by our theory of linkage politics. Today, South Africa is home to more people living with HIV than any other country, where one in five individuals are infected $(17.8 \%$ or approximately 4.2 million people).$^{85}$ In 1997, the Pharmaceutical Manufactures Association of South Africa (PMA), in collaboration with MNCs, challenged the 1994 Medicines Amendment Act that sought to make treatment and access to medicines possible through the acceptance of the parallel importation and the issuing of compulsory licenses. In 1998 the United States Trade Representative (USTR) placed South Africa on the Special 301 Watch List augmenting this challenge. This strong and concerted action was followed by an equally strong civil society action in the US as well as the enhancement of local-global ties within South Africa. Its strong issue and carrier linkage with the global movements aimed to ensure better treatment options for those with HIV. South Africa's dense civil society and mobilization among unions, communist party, and churches led to a massive defeat for the MNCs as well as the USTR's efforts to discipline South

83 Ford et al. (2004: p. 561).

84 Cohen (2007).

85 Beck and Holland (2006: p. 246). 
Africa. In 1999, the multinational lobby (Pharmaceutical Research and Manufacturers of America or PhRMA) announced the suspension of the lawsuit, amounting to a remarkable victory for the fight against HIV/AIDS in South Africa. The strong international issue and carrier linkages did not translate to the domestic sphere, however. Indeed, the government and the local NGOs parted ways, and because of weak issue and carrier linkages, the government did not address the epidemic as they refused to provide access to ARVs in the public sector. ${ }^{86}$ Most concerning, however, was President Mbeki's refusal to acknowledge first, the link between HIV and AIDS and second, the importance of ARV treatment. These developments pitted the domestic civil society against the state, and sundered any potential linkages between the state and society. ${ }^{87}$ This pronounced hostility between civil society and the state, the government's refusal to implement an aggressive public sector-led treatment campaign, and the fragmented view within the South African state regarding treatment ${ }^{88}$ meant that significant legal victories were not followed by a reduction in infection rates.

Our model of linkage politics suggests that the social movement's external linkages are counteracted by the state's attempt to grow as a regional and global power (state's external interest linkage) without alienating MNCs and the US. Most importantly, intra-state issue and carrier linkages are weak and hostile, thus prohibiting social activists from influencing state policy. Though there has been widespread international awareness surrounding HIV/AIDS in South Africa, strong international-domestic issue and carrier linkages are not able to compensate for the obstacles presented by the lack of state-society linkages and the state's external interest linkages aimed at seeking international recognition from investors. The absence of these domestic state-society linkages are also underpinned by racially organized "boundary institutions," ${ }^{89}$ which also prevented a coherent societal response.

Our findings confirm that globalization has not rendered the nation-state powerless. Yet, we argue that this variation across nations is not a confirmation of the pure divergence argument. We present a different, more nuanced, theoretical framework that emphasizes the need to theorize of convergent and divergent

86 Klug (2008).

87 TAC initiated two separate cases against the South African government after 2001 by first, demanding that the government provide mothers and their newborns access to nevirapine, a crucial ARV drug and second, challenging the high prices of ARV drugs in South Africa. Again, TAC emerged victorious in legal and street campaigns empowered by its domestic activism and international networks.

88 There were two different views on treatment within the government: the former Deputy Health Minister supported it and Mbecki, South Africa's President, denied it.

89 Gauri and Lieberman (2006). 
responses together, moving away from dichotomous conceptualizations. The notion developed here of "relative divergence" may better capture the deployment of compliance and global interaction for national purposes by many states. Future avenues of research should focus on this intersection and linkages in other cases and industries.

Acknowledgments: We gratefully acknowledge the excellent comments from anonymous reviewers and the editors of Business and Politics. This paper took shape while both the authors were at University of Wisconsin-Madison. We thank Peter Nasuti and Koffi Yves for their research assistance. Aseema Sinha gratefully acknowledges research funding support from the Salvatori Center at Claremont McKenna College as well as the WAGE Research group at the University of Wisconsin-Madison. This paper was first presented at Comparative Politics Colloquium at University of Wisconsin-Madison. We thank Christina Ewig and Brett Kyle for detailed comments at that workshop. Aili Tripp, Yoshiko Herrera, Michael Schatzberg, Scott Gehlbach, Adam Auerbach and Andrew Reiter also provided us with insightful comments. This paper also benefited from comments from panelists and discussants at the Midwest Political Science Association Conference in 2008; the International Studies Association conference in 2012; and at King's College London in 2013. In particular, we gratefully acknowledge Dr. Pierre Vercauteren for his comments.

Previously published online July 19, 2013

\section{References}

Beck, Eduard J. and Lynn-Marie Holland. 2006. The HIV Pandemic: Local and Global Implications. Oxford: Oxford University Press.

Berkman, Alan, Jonathan Garcia, Miguel Muñoz-Laboy, Vera Paiva, and Richard Parker. 2005.

"A Critical Analysis of the Brazilian Response to HIV/AIDS: Lessons Learned for Controlling and Mitigating the Epidemic in Developing Countries." American Journal of Public Health 95 (7): 1162-1172.

Beyrer, Chris, Varun Gauri, and Denise Vaillancourt. 2005. Evaluation of the World Bank's Assistance in Responding to teh AIDS Epidemic: Brazil Case Study. Washington, DC: The World Bank.

Berman, Peter A. 1998. "Rethinking Health Care Systems: Private Health Care Provision in India." World Development 26 (8): 1463-1479.

Biehl, João. 2004. "The Activist State: Global Pharmaceuticals, AIDS, and Citizenship in Brazil." Social Text 80: 105-132.

Boone, Catherine and Jake Batsell. 2001. "Politics and AIDS in Africa: Research Agendas in Political Science and International Relations." Africa Today 48 (2): 3-33.

Bruce, James. 2003. "Strong medicine - Strategies." Business Network, 23. Accessed February 19, 2008. http://findarticles.com/p/articles/mi_m00QC/is_9_2/ai_100439522. 
Chaudhuri, Sudip. 2005. The WTO and India's Pharmaceuticals Industry: Patent Protection, TRIPS, and Developing Countries. Oxford: Oxford University Press.

Cohen, Jillian Clare. 2000. "Public Policies in the Pharmaceutical Sector: A Case Study of Brazil." The World Bank, LCSHD Paper Series, \#21064.

Cohen, Jillian Clare. 2006. "Expanding Drug Access in Brazil: Lessons for Latin America and Canada." Canadian Journal of Public Health 97 (6): I15-18.

Cohen, Jon. 2007. "Brazil, Thailand Override Big Pharma Patents." Science 316 (5826): 816.

Cohen, Jillian Clare and Kristina M. Lybecker. 2005. "AIDS Policy and Pharmaceutical Patents: Brazil's Strategy to Safeguard Public Health.” World Economy 28 (2): 211-230.

Dube, Siddharth. 1992. "Façade of AIDS Prevention?” Economic and Political Weekly (April 11-18): 757.

Eichengreen, Barry and Jeffry Frieden. 1993. "The Political Economy of European Monetary Unification: An Analytical Introduction.” Economics \& Politics 5 (2): 85-104.

Eimer, Thomas and Susanne Lütz. 2010. "Developmental States, Civil Society, and Public Health: Patent Regulation for HIV/AIDS Pharmaceuticals in India and Brazil." Regulation \& Governance 4 (2): 135-153.

Elias, Paulo Eduardo M and Amelia Cohn. 2003. "Health Reform in Brazil: Lessons to Consider." American Journal of Public Health 93 (1): 44-48.

Flynn, Matthew. 2008. "Public Production of Anti-Retroviral Medicines in Brazill, 1990-2007." Development and Change 39 (4): 513-536.

Flynn, Matthew. 2011. “Corporate Power and State Resistance: Brazil's Use of TRIPS Flexibilities for Its National AIDS Program." In Intellectual Property, Pharmaceuticals and Public Health: Access to Drugs in Developing Countries, edited by Kenneth C. Shadlen, Samira Guennif, Alenka Guzman and N. Lalitha. Cheltenham, UK: Edward Elgar Publishing.

Flynn, Matthew. 2013. "Origins and Limitations of State-Based Advocacy Brazil's AIDS Treatment Program and Global Power Dynamics.” Politics \& Society 41 (1): 3-28.

Frieden, Jeffry and Ronald Rogowski. 1996. "The Impact of the International Economy on National Politices: An Analytical Overview.” In Internationalization and Domestic Politics, edited by Robert 0 . Keohane and Helen V. Milner. Cambridge, MA: Cambridge University Press.

Ford, Nathan, David Wilson, Onanong Bunjumnong and Tido von Schoen Angerer. 2004. "The Role of Civil society in Protecting Public Health over Commercial Interests: Lessons From Thailand." The Lancet 363: 1893-1895.

Galvão, Jane. 2000. AIDS no Brasil: a agenda de construção de uma epidemia. Rio de Janeiro: Editora 34.

Galvão, Jane. 2002. “Access to Antiretroviral Drugs in Brazil.” The Lancet 360: 1862-1865.

Garrett, Geoffrey. 1998. Partisan Politics in the Global Economy. Cambridge, MA: Cambridge University Press.

Gauri, Varun and Evan S. Lieberman. 2006. "Boundary Institutions and HIV/AIDS Policy in Brazil and South Africa." Studies in Comparative International Development 41 (3): 47-73.

Gómez, Eduardo J. 2011. "How Brazil Outpaced the United States When It Came to AIDS: The Politics of Civic Infiltration, Reputation, and Strategic Internationalization." Journal of Health Politics, Policy and Law 36 (2): 317-352.

Gupta, Amit Sen. 2008. "Amendement to the Indian Patents Act” Found at: http://phm-india. org/issues/patents/. Accessed on June 14, 2008.

Keck, Margaret E. and Kathryn Sikkink. 1998. Activists Beyond Borders: Advocacy Networks in International Politics. Ithaca: Cornell University Press. 
Keohane, Robert O. and Helen V. Milner, eds. 1996. Internationalization and Domestic Politics. Cambridge, MA: Cambridge University Press.

Keohane, Robert Owen and Joseph S. Nye. 1977. Power and Interdependence: World Politics in Transition. Little, Brown.

Klug, Heinz 2008. "Law, Politics, and Access to Essential Medicines in Developing Countries," Politics and Society 2008: 207-246.

Kohli, Atul. 2004. State-Directed Development: Political Power and Industrialization in the Global Periphery. Cambridge, MA: Cambridge University Press.

Levi, Guido Carlos and Marco Antonio A Vitória. 2002. "Fighting Against AIDS: The Brazilian Experience." AIDS 16(18): 2373-2383.

Lieberman, Evan S. 2005. "Nested Analysis as a Mixed-Method Strategy for Comparative Research." American Political Science Review 99 (3): 435-452.

Lieberman, Evan S. 2009. Boundaries of Contagion: How Ethnic Politics Have Shaped Government Responses to AIDS. New Jersey, Princeton: Princeton University Press.

Lohmann, Susanne. 1997. “Linkage Politics.” Journal of Conflict Resolution 41 (1): 38-67.

Nag, Moni. 2005. "Sex Workers in Sonagachi: Pioneers of a Revolution." Economic and Political Weekly 40:5151-5156.

Osava, Mario. 2001. "NGOs the Driving Force Behind Public Policy on AIDS." IPS-Press Service. Accessed September 17, 2008. http://ipsnews.net/aids/page_7.shtml

Petchesky, Rosalind P. 2003. "HIV/AIDS and the Human Right to Health: On a Collision Course with Global Capitalism.” In Global Prescriptions: Gendering Health and Human Rights. London, UK: Zed Books.

Pogge, Thomas, Matthew Rimmer and Kim Rubenstein. 2010. "Access to Essential Medicines: Public Health and International Law." In Incentives for Global Public Health: Patent Law and Access to Essential Medicines, edited by Thomas Pogge, Matthew Rimmer and Kim Rubenstein. Cambridge, MA: Cambridge University Press.

Putnam, Robert. 1988. "Diplomacy and Domestic Politics: The Logic of Two-Level Games." International Organization 42 (3): 427-460.

Rangnekar, Dwijen. 2006. “No Pills for Poor People?: Understanding the Disembowelment of India's Patent Regime." Economic and Political Weekly 415: 409-417.

Rosenau, James. 1969. Linkage Politics. New York: The Free Press.

Shadlen, Kenneth C. 2009. "The Politics of Patents and Drugs in Brazil and Mexico: The Industrial Bases of Health Policies." Comparative Politics 42 (1): 41-58.

Sherrll, Kenneth, Carolyn Somerville and Robert Bailey. 1992. "What Political Science Is Missing by Not Studying AIDS." PS: Political Science and Politics, 25 (4): 688-693.

Sinha Aseema (Unpublished book Ms titled: When David Meets Goliath: How Global Trade and Rules are Changing India's Rise to Power).

Supakankunti, S., Janjaroen, W.S., Tangphao, O., Raianawijitrasin, S. 2001. "Impact of the World Trade Organization TRIPS Agreement on the Pharmaceutical Industry in Thailand." Bulletin - World Health Organization 75 (5): 461-470.

Tarrow, Sidney. 2010. "The Strategy of Paired Comparison: Toward a Theory of Practice." Comparative Political Studies 43 (2): 230-259.

Tsebelis, George. 1990. Nested Games: Rational Choice in Comparative Politics. Berkeley, CA: University of California Press.

Vogel, David. 1997. "Trading up and Governing Across: Transnational Governance and Environmental Protection.” Journal of European Public Policy 4 (4): 556-571.

Wade, Robert. 1996. "Japan, the World Bank, and the Art of Paradigm Maintenance: The East Asian Miracle in Political Perspective." New Left Review 217: 124-137. 